\title{
Hydroponic Fertilizer Supply for Basil Using Controlled-release Fertilizer
}

\author{
Fernanda Trientini and Paul R. Fisher \\ Environmental Horticulture Department, University of Florida, Institute of \\ Food and Agricultural Sciences (IFAS), 1549 Fifield Hall, Gainesville, FL \\ 32611-0670
}

Additional index words. small-scale hydroponic, nutrient solution, Ocimum basilicum, slow release

\begin{abstract}
Small-scale hydroponics is a growing urban horticulture trend, but nutrient solution management remains a challenge for small growers. The objective was to investigate the potential to use controlled-release fertilizer (CRF) to simplify nutrient management in small-scale hydroponic systems. Three experiments were conducted with the goal of a single fertilizer application during the crop cycle of basil (Ocimum basilicum). Nutrient release curves were quantified by adding prills to water and measuring nutrient content weekly in the solution for CRF products without plants. In all seven products tested (Osmocote Bloom 2-3M, Osmocote Plus 3-4M, E-Max Calcium Nitrate 2-3M, Agrocote MAP 3-4M, E-Max Keiserite 3-4M, E-Max K-Mag 2-3M, and Agrocote SOP 3-4M) an initial rapid release was followed by a plateau, but release rates differed between products varying from $100 \%\left(\mathrm{MgSO}_{4}\right)$ to $60 \%$ release $\left[\left(\mathrm{NH}_{4}\right) \cdot\left(\mathrm{H}_{2} \mathrm{PO}_{4}\right)\right]$ over an 11-week evaluation period. Total nutrient content in two commercial $\mathrm{N}-\mathrm{P}-\mathrm{K}$ CRF products (3-4 months $15 \mathrm{~N}-3 \mathrm{P}-10 \mathrm{~K}$ and $2-3$ months $12 \mathrm{~N}-3.1 \mathrm{P}-14.9 \mathrm{~K}$ ) provided lower Ca and Mg compared with a typical hydroponic solution based on water-soluble fertilizer (WSF). A subsequent experiment evaluated plant growth response using the same two commercial CRF products (single application) or a WSF (replaced weekly) in growth chamber environment. Plants grown for 4 weeks under CRF treatments yielded less than half the shoot fresh weight of plants grown with WSF and exhibited symptoms of Ca deficiency and micronutrient toxicity (confirmed with tissue analysis). Electrical conductivity (EC) of CRF solutions increased over time indicating excess dose compared with plant uptake, reaching a maximum of $5.4 \mathrm{dS} \cdot \mathrm{m}^{-1}$. Nutrient release curves from the first experiment were then used to estimate product release and create a singleapplication nutritional program based on a customized "Blend" developed from CRF macronutrients plus WSF micronutrients. Plants were grown hydroponically with two dosages of Blend (1X and $2 X)$ and compared with a commercial WSF with weekly replacement of solution. Blend $2 X$ and WSF treatments had similar shoot fresh weight (241 and 244 g/four plants, respectively) with healthy plant appearance and tissue nutrient levels generally within published survey ranges for basil. Commercial CRF products designed for soil or container production were unsuitable for hydroponics, but acceptable plant performance with the customized CRF Blend demonstrated proof-ofconcept for a single CRF application.
\end{abstract}

Almost 42 million U.S. households are engaged in food gardening (National Gardening Association, 2014). Indoor residential food gardening is an increasing trend, with $37 \%$ of millennials growing plants or herbs indoors compared with $28 \%$ of baby boomers (Garden Media Group, 2016). In this context,

\footnotetext{
Received for publication 7 May 2020. Accepted for publication 7 Aug. 2020.

Published online 15 September 2020.

We are thankful for funding from the U.S. Department of Agriculture-Agricultural Research Service Floriculture and Nursery Research Initiative \#58-3607-8-725, and industry partners of the Floriculture Research Alliance at the University of Florida (floriculturealliance.org) for supporting this research.

P.R.F. is the corresponding author. E-mail: pfisher@ ufl.edu.

This is an open access article distributed under the CC BY-NC-ND license (https://creativecommons. org/licenses/by-nc-nd/4.0/).
}

small-scale hydroponics is becoming more popular among homeowners and provides a market opportunity for transplants and growing systems. Closed hydroponics systems are suitable for indoor gardening (Resh, 2013); however, significant technical knowledge is required to successfully manage hydroponic recirculating solutions (Resh, 2015; Savvas et al., 2013).

In commercial production and research, complex methods are used to prepare, deliver, and maintain hydroponic nutrient solutions (Hoagland and Arnon, 1950; Sonneveld and Voogt, 2009; Steiner, 1961). Commercial operations typically use multiple tank systems to avoid undesired nutrient interactions. Optimum nutrient solutions should account for crop growth stage, plant uptake of minerals, substrate characteristics, water quality, and climate conditions (Bugbee, 2004; Hochmuth and Hochmuth, 2018; Trejo-Téllez and Gómez-Merino, 2012). To avoid precipitation and substitution reac- tions, at least two separate stock solutions are typically prepared, one containing calcium and iron, and the other containing sulfates and phosphates. In recirculating hydroponic systems, such as nutrient film technique (NFT) or deep-water culture, changes in ion concentration and $\mathrm{pH}$ over time require constant monitoring and adjustment (Sonneveld and Voogt, 2009). Sophisticated real-time monitoring and control are unlikely to be feasible for smallscale home gardeners.

Controlled-release fertilizers (CRFs) formulated from resin or polymer-coated watersoluble fertilizers are used primarily in substrate and field soil production. Release rates for polymer-coated CRFs are predictable and primarily driven by temperature and coatingmembrane thickness. These coated fertilizers have the potential to be formulated such that nutrient release can be synchronized to plant physiological needs (Du et al., 2006; OzoresHampton, 2017; Trenkel, 2010). The relationship between these two factors allows for a single application of fertilizer rather than multiple low applications of granular or water-soluble fertilizer for substrate and soil production (Liu et al., 2017; Morgan et al., 2009; Oertli, 1980). The typical CRF release patterns are parabolic release (with or without "burst"), linear release, and sigmoidal release (Trenkel, 2010). Nutrient release curves for CRF can be generated by incorporating the CRF in a substrate such as sand, or by monitoring nutrient levels when CRF is placed in an aqueous solution (Adams et al., 2013; Du et al., 2006). Release rates in an aqueous solution vs. substrate can sometimes differ (Du et al., 2006). Solution temperature and $\mathrm{pH}$ are important parameters that affect nutrient release rate (Zografou and Lykas, 2017), with release rate through water diffusion being positively correlated with increasing temperatures (Merhaut et al., 2006).

However, the predictable release pattern of $\mathrm{CRF}$ in aqueous solution indicates the potential to match nutrient availability to plant requirements over time if CRF is used as the nutrient delivery method in hydroponics. The U.S. National Aeronautics and Space Administration has explored the use of slowrelease fertilizers and CRFs in a series of controlled environment agriculture (CEA) simulated space farming trials. Nutrient delivery systems in those trials often included a mix of solid porous ceramic arcillite substrate and CRF, designed to fit the VEGGIE (ORBITEC, Madison, WI) production unit (Massa et al., 2017; Monje et al., 2003). Stutte et al. (2011) successfully used the same production unit to grow three lettuce varieties in a wicking system (where the wick was placed in clear water) fertilized with a 15N-3.9P-10K CRF (Osmocote Plus 15-912; ICL Fertilizers, St. Louis, MO) that was incorporated into the arcillite substrate at 7.5 or $15 \mathrm{~g}$ of fertilizer per $\mathrm{L}$ of substrate.

Other researchers (Albaho et al., 2010; Kinoshita and Masuda, 2011; Schnitzler et al., 2004) have tested CRF in closed irrigation systems that combine aspects of substrate and hydroponic systems. Albaho 
et al. (2010) grew plants in a wicking system in which nutrients were supplied by either a CRF or a granular fertilizer incorporated in the substrate, and water was supplied in a closed reservoir. This system resulted in similar or increased yields of cherry tomato (Lycopersicon esculentum) and peppers (Capsicum frutescens) with CRF compared with granular fertilizer. Kinoshita and Masuda (2011, 2012) and Kinoshita et al. (2014) grew high-wire tomatoes in a range of growing systems in which CRF was either incorporated into the substrate or placed into the reservoir tank, and plant growth and nutrient uptake were compared with water-soluble fertilizer (WSF) in the reservoir. Equivalent yields of tomatoes were possible with CRF use, along with increased nutrient use efficiency, but issues were identified, including the need for nitrification to convert $\mathrm{NH}_{4}{ }^{+}$to $\mathrm{NO}_{3}{ }^{-}$, management of Ca uptake, and appearance of blossom end rot symptoms. Schnitzler et al. (2004) demonstrated that tomato plants could be grown with a combination of slowrelease fertilizer incorporated in the substrate plus WSF supplementation in the nutrient solution as a simplified low-technology approach compared with WSF alone. Therefore, past research indicates that CRF can deliver nutrients in both CEA and greenhouse production and have the potential to simplify nutrient delivery for urban growers.

The hypothesis was that it would be possible to grow hydroponic basil using a single application of CRF with growth performance comparable to a retail hydroponic watersoluble fertilizer that had weekly correction of $\mathrm{pH}$ and replacement of the nutrient solution. The objective was to use CRF to simplify nutrient management in small-scale hydroponic systems by providing adequate nutrition for basil. The approach taken was a) to quantify nutrient release of from a selection of coated (CRF) salts and commercial blends, b) to evaluate plant growth responses to commercial CRF blends developed for soilless substrates, and c) to evaluate plant growth responses to a customized blend of CRF and water-soluble fertilizers.

\section{Materials and Methods}

Expt. A: Nutrient release curves. Release curves for seven CRF products were quantified based on the weekly release of nutrients from each individual product in aqueous solution. The experimental design was a randomized complete block design with three blocks and each CRF as a treatment. Each of the 21 experimental units consisted of a 1.9-L bucket containing a silk bag with one of the seven CRF treatments, described in Table 1, and $1 \mathrm{~L}$ of deionized (DI) water $\left[7.2 \mathrm{mg} \cdot \mathrm{L}^{-1}\right.$ $\mathrm{CaCO}_{3}, 8.8 \mathrm{mg} \cdot \mathrm{L}^{-1} \mathrm{HCO}_{3}{ }^{-}, 0.06 \mu \mathrm{S} \cdot \mathrm{cm}^{-1} \mathrm{EC}$, $\left.1.4 \mathrm{mg} \cdot \mathrm{L}^{-1} \mathrm{Na}^{+}, 5.9 \mathrm{mg} \cdot \mathrm{L}^{-1} \mathrm{Cl}^{-}\right]$. The weight of each CRF product added per liter of water is shown in Table 1. The nutrient release rate was not known before the experiment, but label descriptions were between 2 and 4 months of total release. We therefore assumed that up to half of the fertilizer would release after 4 weeks in the laboratory procedure, and products were standardized by either $\mathrm{N}, \mathrm{K}$, or $\mathrm{Mg}$ content targeting nutrient concentrations that would allow direct analytical measurement without dilution (roughly up to $200 \mathrm{mg} \cdot \mathrm{L}^{-1} \mathrm{~N}$ and $\mathrm{K}$ and $60 \mathrm{mg} \cdot \mathrm{L}^{-1}$ of $\mathrm{Mg}$ per week).

Solutions were measured weekly for $\mathrm{pH}$ and EC $\left(\mathrm{dS} \cdot \mathrm{m}^{-1}\right)$. Average solution temperature during the experiment was $22.4 \pm 1.6{ }^{\circ} \mathrm{C}$ (Hobo UX100; Onset Computer Corporation, Bourne, MA). Each time measurements were taken, solution contents were discarded and buckets replenished with fresh DI water. Samples for days 1, 5, 8, 14, 43, and 77 were analyzed by Quality Analytical Laboratories (Panama City, FL) for complete macro- and micronutrients.

The same products were tested for total nutrient content. Three solid samples for each CRF were ground with $1 \mathrm{~mL}$ of hydrochloric acid $0.1 \mathrm{~N}$ using a mortar and pestle (Table 1).

Table 1. Controlled-release fertilizers tested for nutrient release curves in Expt. A.

\begin{tabular}{|c|c|c|c|}
\hline $\begin{array}{l}\text { Product name and label } \\
\text { duration in months }\end{array}$ & $\begin{array}{l}\text { Nutrient release curve } \\
\text { samples }\left(g \cdot \mathrm{L}^{-1}\right)\end{array}$ & $\begin{array}{l}\text { Solid samples } \\
\left(\mathrm{g} \cdot \mathrm{L}^{-1}\right)\end{array}$ & Treatment \\
\hline Osmocote Bloom 2-3M & 12.7 & 1.65 & CRF Bloom \\
\hline Osmocote Plus 3-4M & 10.1 & 1.35 & CRF Plus \\
\hline E-Max Calcium Nitrate 2-3M & 9.6 & 1 & $\mathrm{Ca}\left(\mathrm{NO}_{3}\right)_{2}$ \\
\hline Agrocote MAP 3-4M & 3.87 & 1 & MAP \\
\hline E-Max Keiserite 3-4M & 3.4 & 1 & $\mathrm{MgSO}_{4}$ \\
\hline E-Max K-Mag 2-3M & 8.5 & 1.55 & K-Mag \\
\hline Agrocote SOP $3-4 \mathrm{M}$ & 4.2 & 1 & $\mathrm{~K}_{2} \mathrm{SO}_{4}$ \\
\hline
\end{tabular}

Milled fertilizer was added to $2 \mathrm{~L}$ of DI water to form nutrient solution samples and analyzed for macro- and micronutrient contents.

The percentage of cumulative release $\left(P_{i j d}\right)$ was calculated for each nutrient element $(i)$ in each fertilizer $(j)$ in each sampled day $(d)$ according to the equation:

$$
P_{i j d}=\frac{\sum_{1}^{d}\left(\text { Creleased }_{i j d}\right)}{\text { Csolid }_{i j}} \times 100
$$

where $\left[\right.$ Creleased $\left._{i j d}\right]$ is the $\mathrm{mg} \cdot \mathrm{g}^{-1}$ of nutrient $i$ from fertilizer $j$ at day $d$, calculated from the total $\mathrm{mg} \cdot \mathrm{L}^{-1}$ of nutrient released by $1 \mathrm{~g}$ of fertilizer $j$ in $1 \mathrm{~L}$ of solution. The parameter Csolid $_{i j}$ in $\mathrm{mg} \cdot \mathrm{g}^{-1}$ represents the nutrient analysis of nutrient $i$ from $1 \mathrm{~g}$ of solid fertilizer $j$ based on the laboratory analysis (Table 2). In cases in which final Creleased Crd $_{2}$ exceeded Csolid $_{i j}$, Creleased $_{i j 77}$ was used to determine $P_{i j d}$. Linear regression was used to relate solution-EC to concentration of each nutrient for each product based on complete data for days $1,5,8,14,43$, and 77 . On sample days when only EC was measured (because of analytical cost), Creleased Crjd $_{\text {was }}$ calculated using linear regression. Equations adopted a linear approach to model the relation between EC measured and nutrient concentration using the datapoints where nutrient concentration information was available. From these modeled curves, nutrient content was estimated for days $21,28,35,49,56,63$, and 70 based on EC measurements. Analysis of variance (ANOVA) was run within individual measurement days on three replicated experimental units per fertilizer treatment, and 95\% confidence intervals for least-square means were estimated using R 3.6.3 (R Core Team, 2020) and emmeans (Lenth, 2020).

Expt. B: Basil plant growth with two commercial CRF products. Growth of hydroponic basil (Ocimum basilicum cv. Genovese) in a growth chamber was compared for five fertilizer treatments, which included "CRF Bloom" (Osmocote Bloom, ICL Fertilizers, St. Louis, MO) and "CRF Plus" (Osmocote Plus, ICL Fertilizers, St. Louis, $\mathrm{MO})$ at two concentrations, and WSF $(10 \mathrm{~N}-$ $5 \mathrm{P}_{2} \mathrm{O}_{5}-14 \mathrm{~K}_{2} \mathrm{O}$ MaxiGRO; General Hydroponics, Sebastopol, CA). From Oct. 22 to Nov. 19, 2018, basil was cultivated hydroponically at Gainesville, FL (lat. $29^{\circ} 38^{\prime} 22^{\prime \prime} \mathrm{N}$, long. $82^{\circ} 21^{\prime} 33^{\prime \prime} \mathrm{W}$ ). Plants were germinated in Rockwool media and were transplanted after $31 \mathrm{~d}$ to hydroponic systems. The experimental design was a randomized complete block design with four blocks and five treatments. Each hydroponic system consisted of

Table 2. Total nutrient content obtained from solid samples $\left(\right.$ Csolid $\left._{i j}\right)$ in Expt. A. Values express $\mathrm{mg}$ of nutrient obtained from $1 \mathrm{~g}$ of milled fertilizer measured by laboratory analysis. Values represent an average of three samples.

\begin{tabular}{|c|c|c|c|c|c|c|c|c|c|c|c|c|c|c|}
\hline & $\mathrm{NH}_{4}{ }^{+}-\mathrm{N}$ & $\mathrm{NO}_{3}{ }^{-}-\mathrm{N}$ & total $\mathrm{N}$ & $\mathrm{P}$ & $\mathrm{K}$ & $\mathrm{Ca}$ & $\mathrm{Mg}$ & $\mathrm{SO}_{4}-\mathrm{S}$ & $\mathrm{Fe}$ & $\mathrm{Mn}$ & $\mathrm{B}$ & $\mathrm{Cu}$ & $\mathrm{Zn}$ & Mo \\
\hline$\overline{\text { CRF Bloom }}$ & 74 & 53 & 127 & 25 & 178 & 9 & 8 & 89 & 0.62 & 0.33 & 0.15 & 0.27 & 0.22 & 0.18 \\
\hline $\mathrm{Ca}\left(\mathrm{NO}_{3}\right)_{2}$ & 10 & 130 & 140 & 0 & 0 & 174 & 5 & 7 & 0.00 & 0.00 & 0.02 & 0.00 & 0.02 & 0.00 \\
\hline K-Mag & 1 & 0 & 1 & 0 & 135 & 10 & 82 & 165 & 0.00 & 0.01 & 0.03 & 0.00 & 0.02 & 0.00 \\
\hline $\mathrm{K}_{2} \mathrm{SO}_{4}$ & 7 & 7 & 14 & 2 & 377 & 7 & 6 & 159 & 0.03 & 0.02 & 0.00 & 0.00 & 0.01 & 0.00 \\
\hline
\end{tabular}


one 4.9-L bucket containing $4 \mathrm{~L}$ of DI water plus one silk bag filled with one fertilizer treatment. Solution aeration was constantly provided on each experimental unit by one 1inch air stone attached to an air pump (Whisper 60; Tetra, Blacksburg, VA). The WSF solutions were discarded and replenished every week with fresh nutrient solution on the same concentration as initial (measured level 204 $\mathrm{mg} \cdot \mathrm{L}^{-1} \mathrm{~N}$ ). For WSF solutions, $\mathrm{pH}$ was adjusted to 6.0 using a commercial potassium hydroxide plus potassium carbonate base solution ("pH UP"; General Hydroponics, Sebastopol, CA). The CRF Bloom and CRF Plus treatments were each applied at two concentrations. Based on release curves from Expt. A, the $1 \mathrm{X}$ fertilizer amount for CRF Bloom and CRF Plus was calculated to release $\approx 200 \mathrm{mg} \mathrm{N}$ per 4 -L container per week. For example, CRF Bloom (12N-3.1P-14.9K) released $28 \%$ of its $\mathrm{N}$ content on the initial $28 \mathrm{~d}$ in Expt. A. Therefore, we used $24 \mathrm{~g}$ of CRF Bloom product to assure a total of $806 \mathrm{mg}$ released after $28 \mathrm{~d}$, equivalent to $\approx 200 \mathrm{mg} \mathrm{N}$ per $4 \mathrm{~L}$ container per week and $50 \mathrm{mg} \cdot \mathrm{L}^{-1} \mathrm{~N}$ per week. In contrast, CRF Plus (15N-3.9P$10 \mathrm{~K} \mathrm{CRF}$ ) released $45 \%$ of $\mathrm{N}$ after $28 \mathrm{~d}$ and 12 $\mathrm{g}$ of CRF Plus was added per container to provide similar nutrient levels to CRF Bloom after 4 weeks. Iron ethylenediamine- $N, N^{\prime}-$ bis(2-hydroxyphenylacetic acid) (FeEDDHA) was added to provide the equivalent of 5 $\mathrm{mg} \cdot \mathrm{L}^{-1} \mathrm{Fe}$ at the $1 \mathrm{X}$ rate of CRF Bloom and CRF Plus, because measured iron levels from Expt. A were close to zero for these products. The chosen $\mathrm{Fe}$ concentration was higher than in the WSF $\left(2.8 \mathrm{mg} \cdot \mathrm{L}^{-1} \mathrm{Fe}\right)$ because FeEDDHA was only applied once and Fe concentration was therefore expected to decrease over time. Both CRF and FeEDDHA were doubled in the $2 \mathrm{X}$ rates of CRF Bloom and CRF Plus. Growth chamber average air temperature was $22.9^{\circ} \mathrm{C} \pm 0.6$ [average of 10 -min intervals obtained from Hobo UX100 (Onset Computer Corporation, Bourne, MA)] and average photosynthetic photon flux was $207.2 \mu \mathrm{mol} \cdot \mathrm{m}^{-2} \cdot \mathrm{s}^{-1}$ (GreenPower; Philips Lighting, Somerset, $\mathrm{NJ} ; 150-\mathrm{cm}$ long) with a photoperiod of $16 \mathrm{~h}$ resulting in a daily light integral of $11.93 \mathrm{~mol} \cdot \mathrm{m}^{-2} \cdot \mathrm{d}^{-1}$.

At the end of the experiment, root and shoot fresh weight were measured. Plants were then oven-dried at $60{ }^{\circ} \mathrm{C}$ for $72 \mathrm{~h}$ and dry weights measured. Final solution-pH and EC were measured using an Orion Versa Star Pro meter (Thermo Fisher Scientific, Beverly, MA). The Soil Plant Analysis Development (SPAD) leaf greenness index was measured in three leaves for each experimental unit using a chlorophyll index meter (SPAD-502; Konica Minolta Sensing Inc., Osaka, Japan). Macro- and micronutrient concentration in solution and plant tissue were determined by Quality Analytical Laboratories (Panama City, FL). Treatment effects were analyzed by ANOVA using R 3.6.3 (R Core Team, 2020) and agricolae package (de Mendiburu, 2020). Pairwise comparisons were made using least-square means and Tukey's honestly significant difference test.
Expt. C: Basil growth in a customized blend of CRF vs. water-soluble fertilizer. A fertilizer blend was developed based on the nutrient release curves from Expt. A. The blend of CRF products at $2 \mathrm{X}$ dosage was developed following these criteria:

1. Release $\approx 1.5 \mathrm{~g} \mathrm{~N}$ in total over a 6 -week period, based on Solis-Toapanta et al. (2020) who found that four hydroponically grown Genovese basil plants in an indoor environment required $2 \mathrm{~g} \mathrm{~N}$ over an 8-week period.

2. Provide a ratio between macronutrients similar to those reported for a "reference" WSF solution [University of Arizona Controlled Environment Agriculture Center solution, described by Mattson and Peters (2014)], of (in $\left.\mathrm{mg} \cdot \mathrm{L}^{-1}\right) 11 \mathrm{NH}_{4}-\mathrm{N}, 178 \mathrm{NO}_{3}-\mathrm{N}, 189 \mathrm{~N}$, $39 \mathrm{P}, 341 \mathrm{~K}, 170 \mathrm{Ca}, 48 \mathrm{Mg}$, and $134 \mathrm{~S}$. As a ratio between nutrients based on $\mathrm{N}$ level, this was equivalent to $1.00 \mathrm{~N}: 0.21$ P:1.8 K:0.90 Ca:0.25 Mg:0.71 S.

Based on the nutrient release curves from Expt. A, we computed the total expected $\mathrm{mg}$ of macronutrient $i$ in blend solution at day $d$. Four CRF products $\{$ E-Max Calcium Nitrate $\left[\mathrm{Ca}\left(\mathrm{NO}_{3}\right)_{2}\right]$, Agrocote MAP (MAP), E-Max $\mathrm{KMag}$ (K-Mag), and Everris 0-0-46 $\left.\left(\mathrm{K}_{2} \mathrm{SO}_{4}\right)\right\}$ (Table 3) contributed to the nutrients in solution. Expected nutrient content from each fertilizer on a specific day was calculated by multiplying the mass $(\mathrm{g})$ of the fertilizer $j$ used in the blend formulation by the Creleased $_{i j d}$ from the same product, obtained in Expt. A. Nutrient content values were summed to compute total nutrient content in CRF Blend solution.

In contrast with a WSF that is replaced every week, the nutrient solution using a single application of CRF would result from the cumulative release of CRF minus uptake by the growing plant over time. Therefore, when a plant is small and early in the crop cycle, the net release of nutrients would be positive, whereas later in the crop cycle plant uptake rate may exceed the nutrient release rate from the CRF.

Micronutrients in water-soluble form were added at the start of the experiment, because limited options of coated micronutrients were commercially available in terms of ratio and form of CRF products. Initial CRF Blend $1 \mathrm{X}$ solution included $2 \mathrm{mg} \cdot \mathrm{L}^{-1} \mathrm{Fe}$ from FeEDDHA, with other micronutrients from a micronutrient blend (Micro Blend; Greencare Fertilizers, Kankakee, IL) at $1 \mathrm{mg} \cdot \mathrm{L}^{-1} \mathrm{Mn}$, $0.5 \mathrm{mg} \cdot \mathrm{L}^{-1} \mathrm{~B}, 0.5 \mathrm{mg} \cdot \mathrm{L}^{-1} \mathrm{Cu}, 1.0 \mathrm{mg} \cdot \mathrm{L}^{-1} \mathrm{Zn}$,

Table 3. CRF Blend composition applied at the $1 \mathrm{X}$ concentrations on Expt. C.

\begin{tabular}{llc}
\hline Fertilizer & Formulation & $\begin{array}{c}\text { CRF Blend at } 1 \mathrm{X} \text { concn } \\
\text { (g per 4-L container) }\end{array}$ \\
\hline Greencare Micro Blend & water-soluble & 0.0475 \\
FeEDDHA & water-soluble & 0.133 \\
E-Max Calcium Nitrate $\left[\mathrm{Ca}\left(\mathrm{NO}_{3}\right)_{2}\right]$ & coated & 9.25 \\
Agrocote MAP $\left[\left(\mathrm{NH}_{4}\right) \cdot\left(\mathrm{H}_{2} \mathrm{PO}_{4}\right)\right]$ & coated & 2.50 \\
E-Max K-Mag $\left[\mathrm{K}_{2} \mathrm{Mg}_{2}\left(\mathrm{SO}_{4}\right)_{3}\right]$ & coated & 1.50 \\
Everris 0-0-46 $\left[\mathrm{K}_{2} \mathrm{SO}_{4}\right]$ & coated & 8.00 \\
\hline
\end{tabular}

$0.2 \mathrm{mg} \cdot \mathrm{L}^{-1}$ Mo. From Expt. B, we observed that a Fe concentration of $5 \mathrm{mg} \cdot \mathrm{L}^{-1}$ was above demand and had not decreased over time as expected. Therefore, $\mathrm{Fe}$ was reduced to 2 $\mathrm{mg} \cdot \mathrm{L}^{-1}$ for the CRF Blend $1 \mathrm{X}$ treatment. All micronutrients concentrations were doubled from CRF Blend $1 \mathrm{X}$ to CRF Blend $2 \mathrm{X}$ treatment.

The experimental design was a randomized complete block design containing four blocks and three treatments (WSF, CRF Blend $1 \mathrm{X}$, and $\mathrm{CRF}$ Blend $2 \mathrm{X}$ ), with two replicates of each treatment per block, totaling 24 deep-water systems. Hydroponic systems used were the same as described in Expt. B. The WSF treatment consisted of 7.6 $\mathrm{g}$ of MaxiGro $\left(10 \mathrm{~N}-2.18 \mathrm{P}-11.6 \mathrm{~K}_{2} \mathrm{O}\right)$ hydroponic fertilizer in $4 \mathrm{~L}$ DI water solution, providing an average $204 \mathrm{mg} \cdot \mathrm{L}^{-1} \mathrm{~N}$. Plants were grown in a growth chamber with 207.2 $\mu \mathrm{mol} \cdot \mathrm{m}^{-2} \cdot \mathrm{s}^{-1}$ (GreenPower $150-\mathrm{cm}$ long fixtures; Philips Lighting) in a $16-\mathrm{h}$ photoperiod during 6 weeks resulting in $11.93 \mathrm{~mol} \cdot \mathrm{m}^{-2} \cdot \mathrm{d}^{-1}$. Average room temperature was $22.7{ }^{\circ} \mathrm{C} \pm$ 0.32 , and solution temperature was $22.4^{\circ} \mathrm{C} \pm$ 0.31 . Blend experimental units were refilled with DI water as needed (water addition was recorded for each replicate). The WSF solutions were discarded and buckets were replenished with fresh nutrient solution once a week. At the end of the experiment, final amount of solution was recorded, and buckets volume was replenished to $4 \mathrm{~L}$ with DI water before $\mathrm{pH}$ and $\mathrm{EC}$ measurements were taken. Other measurements included water consumption over the 6 weeks, root and shoot fresh and dry weights as well as SPAD index. Statistical analysis were conducted similarly to Expt. B.

\section{Results and Discussion}

Expt. A: Nutrient release curves. Patterns of nutrient release over time varied between CRF products in aqueous solution (Fig. 1). Cumulative release curves for CRF Bloom, CRF Plus, $\mathrm{Ca}\left(\mathrm{NO}_{3}\right)_{2}$, MAP, and $\mathrm{K}_{2} \mathrm{SO}_{4}$ showed an initial rapid discharge followed by a linear nutrient release over time. The initial rapid release can be explained by the presence of incompletely coated prills that provide an initial charge of readily soluble nutrients to the solution as described by Shaviv (2005). After this initial phase, ions were released at a fairly constant diffusion rate for these five products until the end of experiment, resulting in between $45 \%$ and $73 \%$ of the macronutrient content after 11 weeks. Magnesium-containing fertilizers $\left(\mathrm{MgSO}_{4}\right.$ and $\left.\mathrm{K}-\mathrm{Mag}\right)$ showed a similar initial 

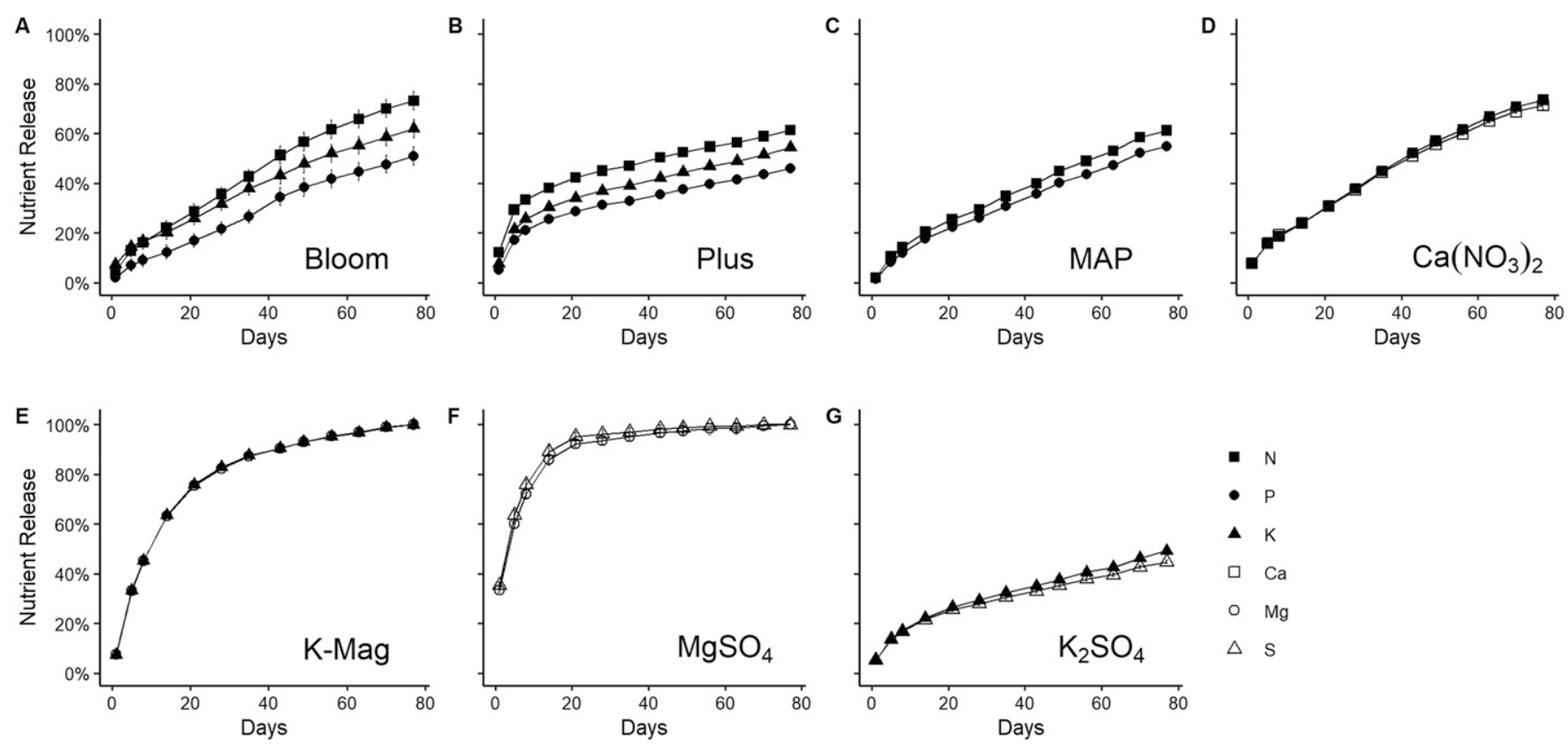

Fig. 1. Cumulative nutrient release curve on a percentage release basis $\left(P_{i j d}\right)$ for seven different controlled-release fertilizers in aqueous solution without plants. Data points represent the cumulative average release of three samples, expressed as a percentage of the nutrient analysis per gram of solid fertilizer from Table 2. Fertilizers were placed in deionized water and solution was changed weekly and nutritional content analyzed for days $1,5,8,14,43$, and 77 . For additional data points, nutrient content was estimated based on linear regression of nutrient content and electrical conductivity. Analysis of variance was run within individual measurement days on three replicated experimental units per fertilizer treatment. On figures $\mathrm{PLUS}, \mathrm{MAP}, \mathrm{Ca}(\mathrm{NO})_{2}, \mathrm{~K}-\mathrm{Mag}_{2} \mathrm{MgSO}_{4}$, and $\mathrm{K}_{2} \mathrm{SO}_{4}, 95 \%$ confidence intervals around least-square mean estimates equaled $\pm 2.6 \%$ and therefore are not visible on graphs.

rapid nutrient phase followed by a diminishing return pattern over time. The $\mathrm{MgSO}_{4}$ product achieved $95 \%$ release after $21 \mathrm{~d}$, although label information indicated full release over 3 to 4 months (Table 1). Different patterns of CRF release result from diverse polymer coating types and thickness, as well as different ion diffusion rates for individual salts as discussed by Oertli (1980) and Trenkel (2010). Correlations between macronutrient concentration in solution and the solution-EC had an average coefficient of determination $\left(R^{2}\right)$ of 0.70 across all 42 interactions analyzed $(6$ macronutrients $\times$ 7 fertilizers).

The release rate of individual macronutrients differed within blended products (Fig. 1). On coated individual salts [MAP, $\mathrm{Ca}\left(\mathrm{NO}_{3}\right)_{2}, \mathrm{~K}_{2} \mathrm{SO}_{4}, \mathrm{MgSO}_{4}$ and $\left.\mathrm{K}-\mathrm{Mag}\right]$, both the cations and the anions in each product were released at similar rate, as expected. In CRF Bloom, the initial faster release rate was faster for $\mathrm{K}$ than $\mathrm{N}$ and $\mathrm{P}$, whereas in $\mathrm{CRF}$ Plus a very similar release pattern among these three macronutrients was observed. Differences observed can be explained by prill distribution and coating of CRF products, whereby all nutrients in CRF Plus are contained in every prill whereas CRF Bloom contained two different types of mini-prills, one composed of resin-coated NPK + micronutrients and the other being resin-coated $\mathrm{K}$ (ICL Fertilizers, St. Louis, MO). After the initial release phase, macronutrients on both the NPK products (CRF Bloom and CRF Plus) had a different release rate between ions, with $\mathrm{P}$ released at a slower rate than $\mathrm{N}$ and $\mathrm{K}$. Other researchers (Broschat and Moore, 2007; Huett and Gogel, 2000) also found slower release of $\mathrm{P}$ relative to $\mathrm{N}$ and $\mathrm{K}$ in mixed CRF products modeled using sand columns. This release behavior was attributed to phosphates having a lower solubility in comparison with the other fertilizer ions, especially $\mathrm{NO}_{3}{ }^{-}$and $\mathrm{NH}_{4}{ }^{+}$(Du et al., 2006).

The cumulative release of CRF tested after 43 d (Table 4) demonstrated a very different ratio between macronutrients compared with the reference hydroponic solution. Although the reference recipe presents a $6 \%$ $\mathrm{NH}_{4}^{+} /$total-N ratio, CRF Bloom and CRF Plus had $55 \%$ and $56 \% \mathrm{NH}_{4}^{+} /$total $\mathrm{N}$ ratio, respectively. This high $\mathrm{NH}_{4}^{+}$ratio could lead to solution acidification and interfere with availability of other cations. The CRF Bloom had an N:P:K ratio (1.0 N:0.1 P:1.18 K) closer to reference $(1.0 \mathrm{~N}: 0.2 \mathrm{P}: 1.8 \mathrm{~K})$, whereas CRF Plus had a much lower K proportion, with $1.0 \mathrm{~N}: 0.15 \mathrm{P}: 0.54 \mathrm{~K}$ ratio. Total nutrient content in commercial mixed CRF (CRF Bloom and CRF Plus) exhibited very low amounts of $\mathrm{Ca}$ and $\mathrm{Mg}$ (Table 2). The reference solution contains almost equal parts of $\mathrm{Ca}$ and $\mathrm{N}$, whereas CRF Bloom and CRF Plus had 1/16 to $1 / 22$ less Ca compared with N. Given the fact that nutrient solutions are often based on $\mathrm{N}$ targets, this would cause CRF-based nutrient solutions to be very low in $\mathrm{Ca}$. The relationship between $\mathrm{Ca}$ and $\mathrm{Mg}$ was also much higher in the reference than in NPK products, with equal parts of both nutrients in CRF Bloom, and $0.6 \mathrm{Ca}: 1.0 \mathrm{Mg}$ in CRF Plus compared with $3.5 \mathrm{Ca}: 1.0 \mathrm{Mg}$ in the reference.

The micronutrient content on CRF prills varied between products. From label information, CRF Bloom and CRF Plus were the only tested CRF products containing micronutrients. Iron form was iron-EDTA in CRF Bloom and a blend of iron phosphate and iron-EDTA in CRF Plus, with other micronutrients in a mineral form. The MAP contained a similar $\mathrm{Fe}$ content to the blended products, which would presumably be in an inorganic mineral form, and showed $\mathrm{Mn}$ content in the acid digestion of solid samples (Table 2). Despite the label information for CRF Bloom not listing copper or zinc content, solid samples contained $0.03 \% \mathrm{Cu}$ and $0.02 \%$ Zn. Both CRF Bloom and CRF Plus had a lower content of $\mathrm{Mn}$ and $\mathrm{Fe}$ in the solid samples than expected from fertilizer label data, and therefore a lower ratio of Fe compared with other micronutrients. During the nutrient release experiment, solution- $\mathrm{pH}$ varied between 5.3 and 7.0, which would be expected to reduce solubility of inorganic $\mathrm{Fe}$, although no sediment formation was observed on containers. Broschat and Moore (2007) described a low release of Fe and Mn when analyzing CRF products and reported that only $10 \%$ of the Mn and $13 \%$ of Fe stated in Osmocote product label information were released after 40 weeks.

The ratio between micronutrients in the solid CRF samples (Table 2) did not match the micronutrient ratio in the reference hydroponic solution. The reference hydroponic solution had a micronutrient ratio based on $\mathrm{Fe}$ level equivalent to $1.00 \mathrm{Fe}: 0.28 \mathrm{Mn}: 0.14$ $\mathrm{B}: 0.03 \mathrm{Cu}: 0.17 \mathrm{Zn}: 0.03 \mathrm{Mo}$. From solid samples of CRF (Table 2), micronutrient ratios were $1.0 \mathrm{Fe}: 0.53 \mathrm{Mn}: 0.24$ B:0.44 $\mathrm{Cu}: 0.35 \mathrm{Zn}: \mathrm{Mo} 0.29$ for CRF Bloom and 1.0 Fe:0.71 Mn:0.40 B:0.84 Cu:0.25 Zn:Mo 
0.53 for CRF Plus. Because micronutrients calculations are often based on Fe content, CRF Bloom and CRF Plus are likely to release high levels of $\mathrm{Cu}$ and $\mathrm{Mo}$, given the high percentage of these nutrients encountered in prills. We found low correlations between micronutrient concentration in solution and the solution-EC in Expt. A (data not shown), with an average coefficient of determination $\left(R^{2}\right)$ of 0.27 across all 42 interactions analyzed. The measured concentration of micronutrients in solutions is further complicated by the combination of low total ion release from prills and the solubility in solu- tion. Overall, micronutrient release in $\mathrm{CRF}$ may be hard to predict in solution, and CRF products designed for container or soil production are unlikely to release micronutrient ratios similar to those typically used in hydroponics and therefore are not a reliable source of micronutrients for hydroponic solutions.

Expt. B: Basil plant growth with two commercial CRF products. Solution-pH dropped during the first $14 \mathrm{~d}$ for all CRF treatments and was fairly stable in the last 2 weeks (Fig. 2B). The $\mathrm{pH}$ initially measured ( $24 \mathrm{~h}$ ) on CRF Blend treatments was between 6.3 and 6.6. After 2 weeks, $\mathrm{pH}$ values ranged

Table 4. Cumulative release values (Creleased $_{i j}{ }_{43}$ ) for the seven fertilizers in Expt. A at day 43 (week 6) Values express mg of nutrient released into solution per gram of fertilizer (average of three samples).

\begin{tabular}{lccrrrrrr}
\hline Fertilizer & $\mathrm{NH}_{4}-\mathrm{N}$ & $\mathrm{NO}_{3}-\mathrm{N}$ & $\mathrm{T}$ tal $\mathrm{N}$ & $\mathrm{P}$ & $\mathrm{K}$ & $\mathrm{Ca}$ & $\mathrm{Mg}$ & $\mathrm{SO}_{4}-\mathrm{S}$ \\
\hline CRF Bloom & 36 & 30 & 65 & 9 & 77 & 4 & 4 & 37 \\
CRF Plus & 124 & 98 & 222 & 34 & 120 & 10 & 16 & 78 \\
$\mathrm{Ca}\left(\mathrm{NO}_{3}\right)_{2}$ & 5 & 68 & 73 & 0 & 0 & 92 & 3 & 5 \\
$\mathrm{MAP}$ & 36 & 0 & 37 & 61 & 2 & 18 & 14 & 25 \\
$\mathrm{KgSO}_{4}$ & 0 & 0 & 0 & 2 & 1 & 13 & 139 & 180 \\
$\mathrm{~K}_{-} \mathrm{Kag}_{2}$ & 0 & 0 & 0 & 0 & 150 & 6 & 94 & 184 \\
$\mathrm{SO}_{4}$ & 0 & 0 & 0 & 0 & 133 & 8 & 7 & 63 \\
\hline
\end{tabular}
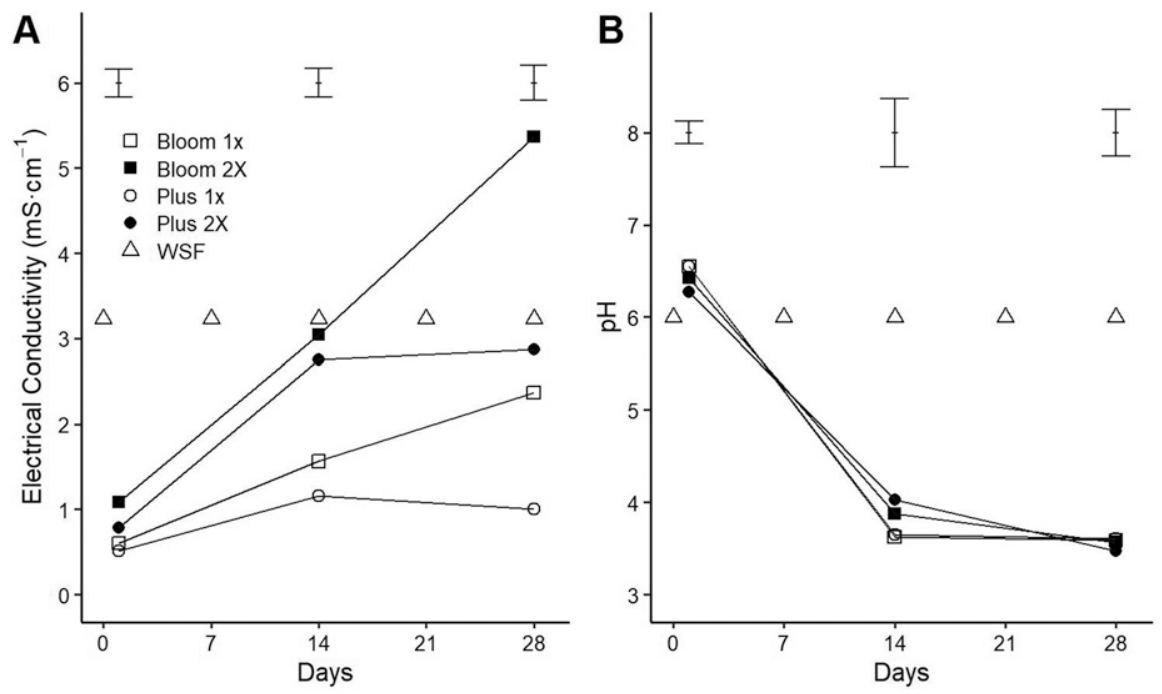

Fig. 2. Nutrient solution electrical conductivity $(\mathbf{A})$ and $\mathrm{pH}(\mathbf{B})$ for nutrient solutions in Expt. B measured after 1, 14, and $28 \mathrm{~d}$. Water-soluble fertilizer (WSF) solution was replaced every week with fresh solution containing $190 \mathrm{mg} \cdot \mathrm{L}^{-1} \mathrm{~N}$ in deionized water. The $\mathrm{pH}$ level for WSF shown in this figure represents the initial $\mathrm{pH} 6.0$ for fresh solution after adjusting $\mathrm{pH}$ each week with a blended potassium hydroxide plus potassium carbonate base. The $\mathrm{pH}$ was not corrected in the controlled-release fertilizer treatments. Analysis of variance was run within individual measurement days on four replicated experimental units per fertilizer treatment. Error bars represent the $95 \%$ confidence intervals around estimated least-square means. from 3.6 to 4.0 , and final $\mathrm{pH}$ values for those treatments was close to 3.6 , indicating an unfavorable $\mathrm{pH}$ range for plant growth. This acidification in CRF treatments most likely resulted from the high percentage of ammoniacal nitrogen in fertilizers $(53 \%$ in $\mathrm{CRF}$ Plus and $56 \%$ in CRF Bloom according to label information). Low alkalinity of DI water $\left(7.2 \mathrm{mg} \cdot \mathrm{L}^{-1} \mathrm{CaCO}_{3}\right)$ resulted in very low buffer capacity of solution. When fresh WSF solution was prepared, the mix of WSF and DI water instantly generated a $\mathrm{pH} 4.2$ solution (DI water $\mathrm{pH}$ was 4.8). Therefore, addition of a base ("pH UP," General Hydroponics, Sebastopol, CA) was needed to return solution-pH to 6.0 each week when fresh WSF solution was prepared. After $\mathrm{pH}$ was adjusted to 6.0, WSF solutions dropped in $\mathrm{pH}$ over the following $7 \mathrm{~d}$ before solution replacement occurred. For example, between days 7 and 14 the $\mathrm{pH}$ dropped from 6.0 to 4.3 , before solution replenishment (not represented in Fig. 2B) and subsequent $\mathrm{pH}$ base adjustment.

The EC increased in all CRF treatments over time (Fig. 2A), indicating that fertilizers released nutrients faster than the ions were taken up by plants. In nutrient solutions containing CRF Bloom, EC levels increased over time. In CRF Plus solutions, nutrient release from prills appeared similar to plant uptake after day 14, based on a fairly constant EC between weeks 2 and 4 . All CRF treatments except CRF Bloom 2X had EC values lower than the EC of the WSF treatment $\left(3.2 \mathrm{dS} \cdot \mathrm{m}^{-1}\right.$ when solution was replaced each week).

All plants grown with CRF treatments showed reduced leaf expansion and darker green coloration when compared with those grown in the WSF, which appeared healthy (Fig. 3). Multiple disorders were observed in the plants grown with CRF treatments, with visual symptoms including tip burn and leaf distortion. These nutritional disorders led to lower basil fresh and dry weights for plants under CRF treatments compared with those grown with WSF (Table 5). The CRF-grown plants showed higher SPAD index than plants grown with WSF (Table 5) and exhibited dark green leaf coloration (Fig. 3). Greater water consumption was observed for plants grown with WSF compared with CRF treatments (Table 5), which was probably a result of the greater leaf area observed for basil grown under WSF treatment.

Symptoms observed in CRF-grown plants were consistent with copper toxicity and calcium deficiency described by Sonneveld and Voogt (2009). Despite the low $\mathrm{Mg}$

Table 5. Growth parameters of basil cultivated in growth chamber for 4 weeks with nutrient solution from water-soluble fertilizer (WSF) or commercial controlled-release fertilizer (CRF) blends in Expt. B.

\begin{tabular}{|c|c|c|c|c|c|c|c|c|}
\hline \multirow[b]{2}{*}{ Treatment } & Shoot & Root & Total & Shoot & Root & Total & \multirow[b]{2}{*}{ SPAD index } & \multirow{2}{*}{$\begin{array}{l}\text { Water consumption } \\
\left(\mathrm{mL} \cdot \mathrm{g}^{-1} \text { fresh wt) }\right.\end{array}$} \\
\hline & \multicolumn{3}{|c|}{ Fresh wt (g/four plants) } & \multicolumn{3}{|c|}{ Dry wt (g/four plants) } & & \\
\hline CRF Bloom 1X & $89 \mathrm{~b}$ & $48 \mathrm{~b}$ & $137 \mathrm{~b}$ & $8.5 \mathrm{~b}$ & $4.7 \mathrm{~b}$ & $13 \mathrm{~b}$ & $48 \mathrm{a}$ & $23 \mathrm{~b}$ \\
\hline CRF Plus $2 \mathrm{X}$ & $93 \mathrm{~b}$ & $54 \mathrm{~b}$ & $146 \mathrm{~b}$ & $8.1 \mathrm{~b}$ & $4.6 \mathrm{~b}$ & $13 \mathrm{~b}$ & $48 \mathrm{a}$ & $10 \mathrm{~b}$ \\
\hline ANOVA & $* * *$ & $* * *$ & $* * *$ & $* * *$ & $* * *$ & $* * *$ & $* * *$ & $* *$ \\
\hline
\end{tabular}

** $P<0.01,{ }^{* * *} P<0.001$. Pairwise comparison between the treatments used Tukey's honestly significant difference test at the $5 \%$ level. 
concentration encountered in tissue samples (Table 6) and in the residual nutrient solution (Table 7), no visual symptom of $\mathrm{Mg}$ deficiency was observed. The apparent $\mathrm{Ca}$ deficiency was confirmed by the low $\mathrm{Ca}$ content in both the tissue (Table 6) and the residual nutrient solution analyses (Table 7). Multiple factors contributed to this result, including the low $\mathrm{Ca}$ content in CRF products tested and unbalanced ratios between nutrients observed in Expt. A. Kinoshita and Masuda (2012) grew tomatoes in a wicking system with CRF placed in the irrigation reservoir, and also observed $\mathrm{Ca}$ deficiency symptoms. In both our study and the Kinoshita and Masuda (2012) experiment, CRF products had a high ammonium content, which is likely to suppress $\mathrm{Ca}$ absorption and favor $\mathrm{NH}_{4}{ }^{+}$uptake due to differential cation uptake by plant. Similar causes led to a small $\mathrm{Mg}$ percentage observed in plant tissue analysis (Table 6). Levels of N, P, and $\mathrm{K}$ were adequate to high for plants grown in all treatments (Table 6).

The combination of high levels of $\mathrm{Fe}, \mathrm{Cu}$, and $\mathrm{Zn}$ in solution (Table 7) and the low solution-pH (Fig. 2A) increased the risk of micronutrient toxicities from CRF treatments, especially in $2 \mathrm{X}$ dosages. The high Fe verified in tissue sample analysis (Table 6) indicate that the amount of FeEDDHA we added to the CRF treatments was overestimated and could be reduced in future experiments. High levels of $\mathrm{Fe}, \mathrm{Cu}, \mathrm{Zn}$, and Mo were observed in plant tissue (Table 6). Leaves showed multiple nutritional disorder symptoms, including chlorosis on new leaves and long narrow-shaped leaves, which were likely related to micronutrients toxicities. Abnormal lateral root formation was observed and was interpreted as a symptom of copper toxicity, particularly evident in plants grown under CRF Bloom $1 \mathrm{X}$ and $2 \mathrm{X}$ treatments.

Expt. C: Basil growth in a customized blend of CRF vs. water-soluble salts. Based on the nutrient release curves in Expt. A, it was possible to formulate a customized blend of CRF products that would be expected to result in similar ratios to the "reference" solution (Table 8). Given the Ca deficiency symptoms observed in Expt. B, we aimed to assure adequate supply of $\mathrm{Ca}$ in the CRF Blend using $\mathrm{Ca}\left(\mathrm{NO}_{3}\right)_{2}$, which also provided

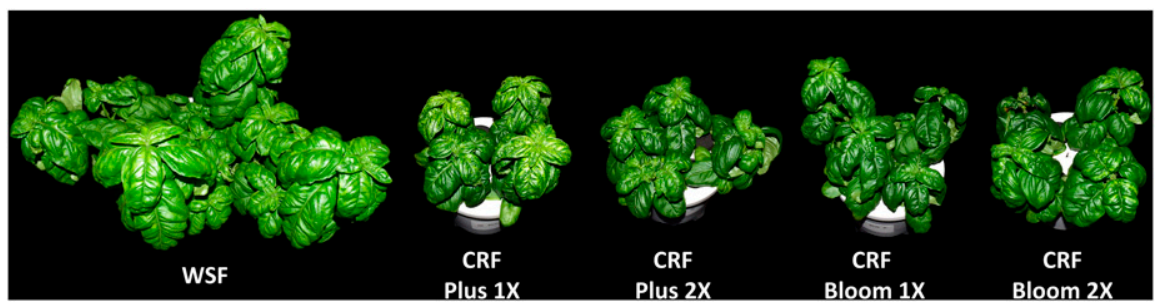

Fig. 3. Visual comparison between plants grown in the growth chamber under water-soluble fertilizer (WSF) and commercial controlled-release fertilizers (CRF) CRF Bloom and CRF Plus solutions on day 28 of Expt. B.

$\mathrm{NO}_{3}-\mathrm{N}$ to avoid excess acidification. Similarly, Kinoshita et al. (2016) also based their $\mathrm{CRF}$ formulation with $\mathrm{Ca}\left(\mathrm{NO}_{3}\right)_{2}$ products while developing a CRF-based nutrient management strategy for tomato production in closed hydroponic systems. A practical concern with scaling up this approach is the limited commercial availability of coated $\mathrm{Ca}\left(\mathrm{NO}_{3}\right)_{2}$. Other than the high $\mathrm{Ca}$ [from $\mathrm{Ca}\left(\mathrm{NO}_{3}\right)_{2}$ ] and $\mathrm{S}$ (from $\mathrm{K}_{2} \mathrm{SO}_{4}$ ), macronutrient ratios in CRF Blend were similar to those observed in WSF fertilizer and reference solutions (Table 8). Expts. A and B results indicated that a very low content of micronutrients should be expected from individual minerals used to formulate CRF Blend and FeEDDHA and water-soluble micronutrients were therefore included in the formulation at a single initial dose (Table 3 ) with the expectation that these ions would be taken up over the 6-week experiment duration.

All three treatments resulted in healthy plants, with standard leaf expansion and coloration, and CRF-grown plants had similar growth to those under the WSF treatment (Fig. 4). All three fertilizer treatments resulted in plants with equivalent fresh weight (Table 9). However, the CRF Blend $2 \mathrm{X}$ and WSF resulted in plants with similar dry weights, whereas CRF Blend $1 \mathrm{X}$ had slightly less shoot and total dry mass. The SPAD values did not differ among the three treatments and water consumption was $18 \%$ higher for plants grown with WSF than with CRF Blend 2X. Kinoshita et al. $(2014,2016)$ grew tomato in a closed CRF-fertilized hydroponic system and a WSF-fertilized ECbased open drip system. The similar yield observed by Kinoshita et al. $(2014,2016)$ in the two systems provides more evidence that

Table 6. Nutritional tissue analysis from basil cultivated in growth chamber for 4 weeks with nutrient solution made from water-soluble fertilizer (WSF) or commercial controlled-release fertilizer (CRF) blends in Expt. B. Pairwise comparison between the treatments used Tukey's honestly significant difference test at the $5 \%$ level.

\begin{tabular}{|c|c|c|c|c|c|c|c|c|c|c|c|c|}
\hline \multirow[b]{2}{*}{ Treatment } & $\mathrm{N}$ & $\mathrm{P}$ & $\mathrm{K}$ & $\mathrm{Ca}$ & $\mathrm{Mg}$ & $\mathrm{S}$ & $\mathrm{Fe}$ & $\mathrm{Mn}$ & B & $\mathrm{Cu}$ & $\mathrm{Zn}$ & Mo \\
\hline & \multicolumn{6}{|c|}{$(\%)$} & \multicolumn{6}{|c|}{$\left(\mathrm{mg} \cdot \mathrm{kg}^{-1}\right)$} \\
\hline$\overline{\mathrm{WSF}}$ & $5.2 \mathrm{ab}$ & $1.3 \mathrm{a}$ & $6.4 \mathrm{a}$ & $1.3 \mathrm{a}$ & $0.5 \mathrm{a}$ & $0.5 \mathrm{~b}$ & $325 \mathrm{c}$ & $331 \mathrm{a}$ & $31 \mathrm{~b}$ & $15 \mathrm{c}$ & $68 \mathrm{c}$ & $8 \mathrm{~d}$ \\
\hline CRF Bloom 1X & $5.0 \mathrm{~b}$ & $0.7 \mathrm{~b}$ & $4.3 \mathrm{bc}$ & $0.3 \mathrm{~b}$ & $0.2 \mathrm{c}$ & $0.6 \mathrm{ab}$ & $1581 \mathrm{ab}$ & $123 \mathrm{~b}$ & $31 \mathrm{~b}$ & $177 \mathrm{ab}$ & $145 \mathrm{bc}$ & $38 \mathrm{c}$ \\
\hline CRF Bloom 2X & $5.8 \mathrm{a}$ & $1.2 \mathrm{a}$ & $6.0 \mathrm{a}$ & $0.3 \mathrm{~b}$ & $0.2 \mathrm{bc}$ & $0.8 \mathrm{a}$ & $1467 \mathrm{~b}$ & $165 \mathrm{~b}$ & $44 \mathrm{a}$ & $247 \mathrm{a}$ & $278 \mathrm{~b}$ & $64 \mathrm{ab}$ \\
\hline CRF Plus 1X & $5.3 \mathrm{ab}$ & $0.8 \mathrm{~b}$ & $3.3 \mathrm{c}$ & $0.4 \mathrm{~b}$ & $0.3 \mathrm{bc}$ & $0.6 \mathrm{ab}$ & $1583 \mathrm{ab}$ & $110 \mathrm{~b}$ & $34 \mathrm{~b}$ & $167 \mathrm{~b}$ & $214 \mathrm{~b}$ & $45 \mathrm{bc}$ \\
\hline CRF Plus 2X & $5.8 \mathrm{a}$ & $1.4 \mathrm{a}$ & $5.2 \mathrm{ab}$ & $0.3 \mathrm{~b}$ & $0.3 \mathrm{~b}$ & $0.8 \mathrm{a}$ & $2059 \mathrm{a}$ & $167 \mathrm{~b}$ & $44 \mathrm{a}$ & $184 \mathrm{ab}$ & $453 \mathrm{a}$ & $76 \mathrm{a}$ \\
\hline Survey range ${ }^{z}$ & 4-6 & $0.62-1.0$ & $1.55-2.05$ & $1.25-2.00$ & $0.6-1.0$ & $0.2-0.6$ & $75-200$ & $30-150$ & $25-60$ & $5-10$ & $30-70$ & $0.1-0.5$ \\
\hline ANOVA $^{\mathrm{y}}$ & $* *$ & $* * *$ & $* * *$ & $* * *$ & $* * *$ & $* *$ & $* * *$ & $* *$ & $* *$ & $* * *$ & $* * *$ & $* * *$ \\
\hline
\end{tabular}

${ }^{\mathrm{z}}$ Survey ranges from field and garden-grown basil plants in Bryson and Mills (2014).

${ }^{\mathrm{y}}$ Analysis of variance statistical test do not include survey ranges.

$* * P<0.01, * * * P<0.001$. Pairwise comparison between the treatments used Tukey's honestly significant difference test at the $5 \%$ level.

Table 7. Residual nutrient solution concentrations after basil was cultivated in growth chamber for 4 weeks with nutrient solution made from water-soluble fertilizer (WSF) or commercial controlled-release fertilizer (CRF) in Expt. B. Results for WSF represent depletion of solution over $7 \mathrm{~d}$ (week 3 to week 4 ).

\begin{tabular}{|c|c|c|c|c|c|c|c|c|c|c|c|c|c|c|}
\hline & $\mathrm{NH}_{4}{ }^{+}-\mathrm{N}$ & $\mathrm{NO}_{3}{ }^{-}-\mathrm{N}$ & total $\mathrm{N}$ & $\mathrm{P}$ & $\mathrm{K}$ & $\mathrm{Ca}$ & $\mathrm{Mg}$ & $\mathrm{SO}_{4}-\mathrm{S}$ & $\mathrm{Fe}$ & $\mathrm{Mn}$ & B & $\mathrm{Cu}$ & $\mathrm{Zn}$ & Mo \\
\hline Treatment & \multicolumn{14}{|c|}{$\left(\mathrm{mg} \cdot \mathrm{L}^{-1}\right)$} \\
\hline$\overline{\mathrm{WSF}}$ & $3 \mathrm{e}$ & $164 \mathrm{~b}$ & $167 \mathrm{c}$ & $29 \mathrm{a}$ & $296 \mathrm{~b}$ & $147 \mathrm{a}$ & $78 \mathrm{a}$ & $112 \mathrm{c}$ & $4.5 \mathrm{c}$ & $0.09 \mathrm{c}$ & $0.44 \mathrm{~b}$ & $0.3 \mathrm{~d}$ & $1.0 \mathrm{~b}$ & $0.14 \mathrm{a}$ \\
\hline CRF Bloom 1X & $104 \mathrm{c}$ & $70 \mathrm{~d}$ & $173 \mathrm{c}$ & $11 \mathrm{bc}$ & $220 \mathrm{c}$ & $27 \mathrm{~b}$ & $18 \mathrm{c}$ & $164 \mathrm{~b}$ & $6.6 \mathrm{c}$ & $0.79 \mathrm{~b}$ & $0.32 \mathrm{c}$ & $2.8 \mathrm{c}$ & $1.2 \mathrm{~b}$ & $0.05 \mathrm{~b}$ \\
\hline CRF Bloom 2X & $304 \mathrm{a}$ & $223 \mathrm{a}$ & $527 \mathrm{a}$ & $28 \mathrm{a}$ & $545 \mathrm{a}$ & $36 \mathrm{~b}$ & $28 \mathrm{~b}$ & $331 \mathrm{a}$ & $12.1 \mathrm{a}$ & $1.33 \mathrm{a}$ & $0.78 \mathrm{a}$ & $6.1 \mathrm{a}$ & $2.3 \mathrm{a}$ & $0.12 \mathrm{a}$ \\
\hline CRF Plus 1X & $46 \mathrm{~d}$ & $24 \mathrm{e}$ & $70 \mathrm{~d}$ & $4.0 \mathrm{c}$ & $6.6 \mathrm{e}$ & $26 \mathrm{~b}$ & $21 \mathrm{c}$ & $82 \mathrm{~d}$ & $5.8 \mathrm{c}$ & $0.58 \mathrm{~b}$ & $0.15 \mathrm{~d}$ & $2.2 \mathrm{c}$ & $0.9 \mathrm{~b}$ & $0.04 \mathrm{~b}$ \\
\hline CRF Plus 2X & $166 \mathrm{~b}$ & $117 \mathrm{c}$ & $283 \mathrm{~b}$ & $26 \mathrm{ab}$ & $129 \mathrm{~d}$ & $30 \mathrm{~b}$ & $33 \mathrm{~b}$ & $163 \mathrm{~b}$ & $9.5 \mathrm{~b}$ & $0.83 \mathrm{~b}$ & $0.40 \mathrm{bc}$ & $4.8 \mathrm{~b}$ & $2.2 \mathrm{a}$ & $0.11 \mathrm{a}$ \\
\hline ANOVA & $* * *$ & $* * *$ & $* * *$ & $* * *$ & $* * *$ & $* * *$ & $* * *$ & $* * *$ & $* * *$ & $* * *$ & $* * *$ & $* * *$ & $* * *$ & $* * *$ \\
\hline
\end{tabular}

$* * * P<0.001$. Pairwise comparison between the treatments used Tukey's honestly significant difference test at the $5 \%$ level. 
Table 8. Comparison of several nutrient solutions without plants, including a commercial water-soluble fertilizer [WSF (MaxiGro)], "reference" water-soluble solution from Mattson and Peters (2014), and custom controlled-release fertilizer (CRF) Blend tested in Expt. C after 6 weeks. Custom CRF Blend values are based on the individual release curves for the formulation in Table 3. Micronutrient concentrations for Custom CRF Blends $1 \mathrm{X}$ are the initial water-soluble concentration. The fertilizer concentration represents the grams of product added per liter of solution.

\begin{tabular}{|c|c|c|c|c|c|c|c|c|c|c|c|c|c|c|c|}
\hline & Fertilizer & $\mathrm{NH}_{4}^{+}-\mathrm{N}$ & $\mathrm{NO}_{3}{ }^{-}-\mathrm{N}$ & total-N & $\mathrm{P}$ & $\mathrm{K}$ & $\mathrm{Ca}$ & $\mathrm{Mg}$ & $\mathrm{SO}_{4}-\mathrm{S}$ & $\mathrm{Fe}$ & $\mathrm{Mn}$ & B & $\mathrm{Cu}$ & $\mathrm{Zn}$ & Mo \\
\hline Treatment & $\left(\mathrm{g} \cdot \mathrm{L}^{-1}\right)$ & \multicolumn{14}{|c|}{$\left(\mathrm{mg} \cdot \mathrm{L}^{-1}\right)$} \\
\hline$\overline{\text { WSF (MaxiGro) }}$ & 7.6 & 22 & 181 & 204 & 48 & 303 & 115 & 54 & 74 & 2.78 & 0.70 & 0.32 & 0.20 & 0.36 & 0.04 \\
\hline $\begin{array}{l}\text { Mattson and Peters (2014) } \\
\text { "reference" }\end{array}$ & 1.9 & 11 & 178 & 189 & 39 & 341 & 170 & 48 & 134 & 2.00 & 0.55 & 0.28 & 0.05 & 0.33 & 0.05 \\
\hline Custom CRF Blend 1X (day 43) & 5.4 & 35 & 157 & 192 & 39 & 324 & 243 & 65 & 221 & 2.0 & 1.0 & 0.5 & 0.5 & 1.0 & 0.2 \\
\hline
\end{tabular}

Table 9. Growth parameters for basil cultivated in a growth chamber for 6 weeks with nutrient solution made from water-soluble fertilizer (WSF) or customized controlled-release fertilizer (CRF) blend in Expt. C. Pairwise comparison between the treatments used Tukey's honestly significant difference test at the 5\% level.

\begin{tabular}{|c|c|c|c|c|c|c|c|c|}
\hline \multirow[b]{2}{*}{ Treatment } & Shoot & Root & Total & Shoot & Root & Total & \multirow[b]{2}{*}{ SPAD index } & \multirow{2}{*}{$\begin{array}{l}\text { Water consumption } \\
\left(\mathrm{mL} \cdot \mathrm{g}^{-1} \text { fresh } \mathrm{wt}\right)\end{array}$} \\
\hline & \multicolumn{3}{|c|}{ Fresh wt (g/four plants) } & \multicolumn{3}{|c|}{ Dry wt (g/four plants) } & & \\
\hline$\overline{\mathrm{WSF}}$ & 241 & 167 & 409 & $16.7 \mathrm{a}$ & 10.4 & $27.1 \mathrm{ab}$ & 35.9 & $13.8 \mathrm{a}$ \\
\hline CRF Blend $1 \mathrm{X}$ & 199 & 199 & 398 & $13.1 \mathrm{~b}$ & 11.1 & $24.2 \mathrm{~b}$ & 38.1 & $10.8 \mathrm{~b}$ \\
\hline CRF Blend 2X & 244 & 185 & 429 & $18.5 \mathrm{a}$ & 11.3 & $29.8 \mathrm{a}$ & 35.8 & $11.1 \mathrm{~b}$ \\
\hline ANOVA & NS & NS & NS & $* * *$ & NS & $* *$ & NS & $* *$ \\
\hline
\end{tabular}

NS $=$ nonsignificant, ${ }^{*} * P<0.01, * * * P<0.001$. Pairwise comparison between the treatments used Tukey's honestly significant difference test at the $5 \%$ level.
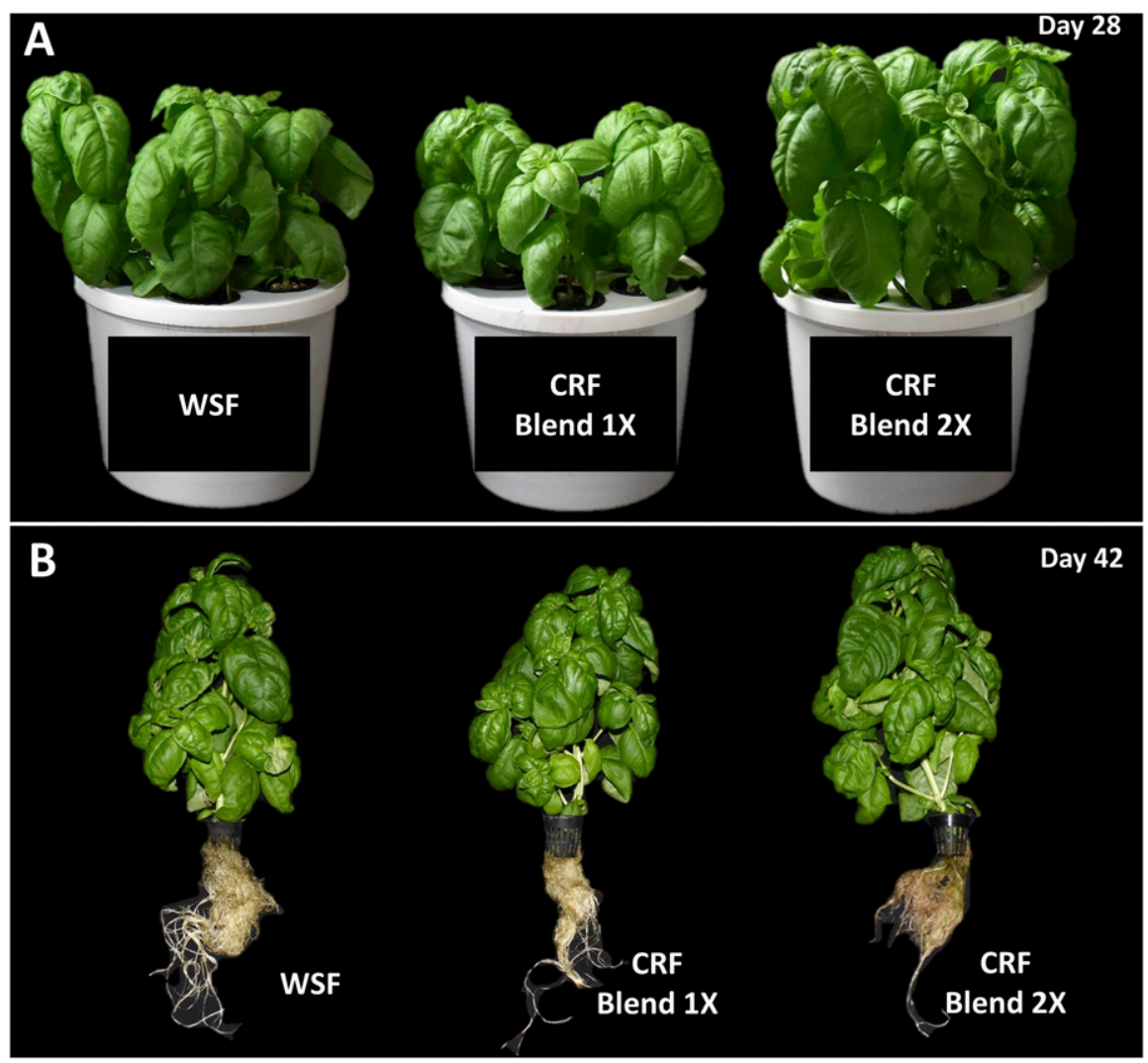

Fig. 4. Visual comparison of basil grown under water-soluble fertilizer (WSF) and controlled-release fertilizers (CRF) CRF Blend $1 \mathrm{X}$ and CRF Blend 2X fertilizer treatments on days 28 (A) or 42 (B) of Expt. C.

CRF use in hydroponics could be expanded to other horticultural crops.

Changes in solution-pH over time were observed for the CRF treatments in Expt. C (Fig. 5B). With the CRF $1 \mathrm{X}$ treatment, solution-pH dropped during the initial 3 weeks and then slowly rose to 5.9 at the harvest time (Fig. 5B). In the CRF $2 \mathrm{X}$ treatment, solution-pH decreased to $\mathrm{pH} 4$ over the initial 4 weeks and then stabilized. In the close to the 4 to $7 \mathrm{pH}$ range proposed by Bugbee (2004). Our observation of normal plant growth even when solution-pH was low is in accordance with Gillespie et al. (2020), who found that hydroponic basil exhibited similar growth at $\mathrm{pH}$ between 4.0 and 5.5.

The EC values measured resulted from the balance between CRF nutrient release and plant nutrient uptake. On CRF Blend $2 \mathrm{X}$ solutions, EC increased over the initial 4 weeks and peaked at week 5 , after which started to decrease (Fig. 5A). For CRF Blend $1 \mathrm{X}$ solutions, EC increased on the initial 3 weeks, reaching a maximum of $1.4 \mathrm{dS} \cdot \mathrm{m}^{-1}$, after that it started decreasing again until harvest, where it achieved $0.9 \mathrm{dS} \cdot \mathrm{m}^{-1}$. This behavior indicates that plant nutrient uptake exceeded nutrient release after day 21 for CRF Blend $1 \mathrm{X}$ and after day 35 for CRF Blend 2X. The EC range over the entire production cycle was between 0.9 and 3.4 $\mathrm{dS} \cdot \mathrm{m}^{-1}$ for CRF treatments and 1.6 to 3.2 $\mathrm{dS} \cdot \mathrm{m}^{-1}$ for WSF. No salinity damage was observed in roots, and Walters and Currey (2018) found similar growth rates and healthy growth with nutrient solution-EC levels between 0.5 and $4 \mathrm{dS} \cdot \mathrm{m}^{-1}$ for hydroponically grown basil.

Overall, the CRF Blend $2 \mathrm{X}$ dosage provided a closer match to plant nutritional demand over 6 weeks than CRF Blend 1X. Residual solution analysis (Table 10) indicates almost complete depletion of $\mathrm{N}, \mathrm{P}$, and $\mathrm{K}$ in the CRF Blend $1 \mathrm{X}$ treatment. That result indicates that CRF Blend $1 \mathrm{X}$ dosage would release sufficient nutrients in solution to grow basil only on the initial 5 to 6 weeks, when plants are smaller and nutrient demand is lower, demanding a new fertilizer addition if the crop cycle was continued.

With CRF Blend 2X, the residual nutrient concentration in solution at the end of week 6 was lower than the residual concentration from the WSF remaining at week 6 (after 1 week since nutrient replacement). However, based on the nutrient release curves from Expt. A, the CRF Blend main components 
$\left[\mathrm{Ca}\left(\mathrm{NO}_{3}\right)_{2}, \mathrm{~K}_{2} \mathrm{SO}_{4}\right.$ and MAP] would continue to release nutrients after week 6 . The analysis of the nutrient solution, with lower concentrations of nutrients from CRF Blend $2 \mathrm{X}$ than in WSF should be interpreted with the appreciation that roughly half of CRF nutrient would still be inside the fertilizer prill at week 6 (based on Fig. 1), and therefore were not detected in solution analysis. In addition, Bugbee (2004) pointed out that low ion concentration in solution does not necessarily imply a deficiency in the plant, rather it can indicate a healthy plant with rapid nutrient uptake. The only macronutrient that would be depleted after 6 weeks in CRF Blend 2X would be expected to be $\mathrm{Mg}$, because the CRF source (KMag) used released $90 \%$ of its $\mathrm{Mg}$ content by day 42 (Expt. A, Fig. 1).

Tissue analysis revealed low macronutrient content in plants grown under CRF Blend $1 \mathrm{X}$ and high micronutrient content in those under CRF Blend 2X. Basil grown on CRF Blend $2 \mathrm{X}$ solutions showed adequate levels
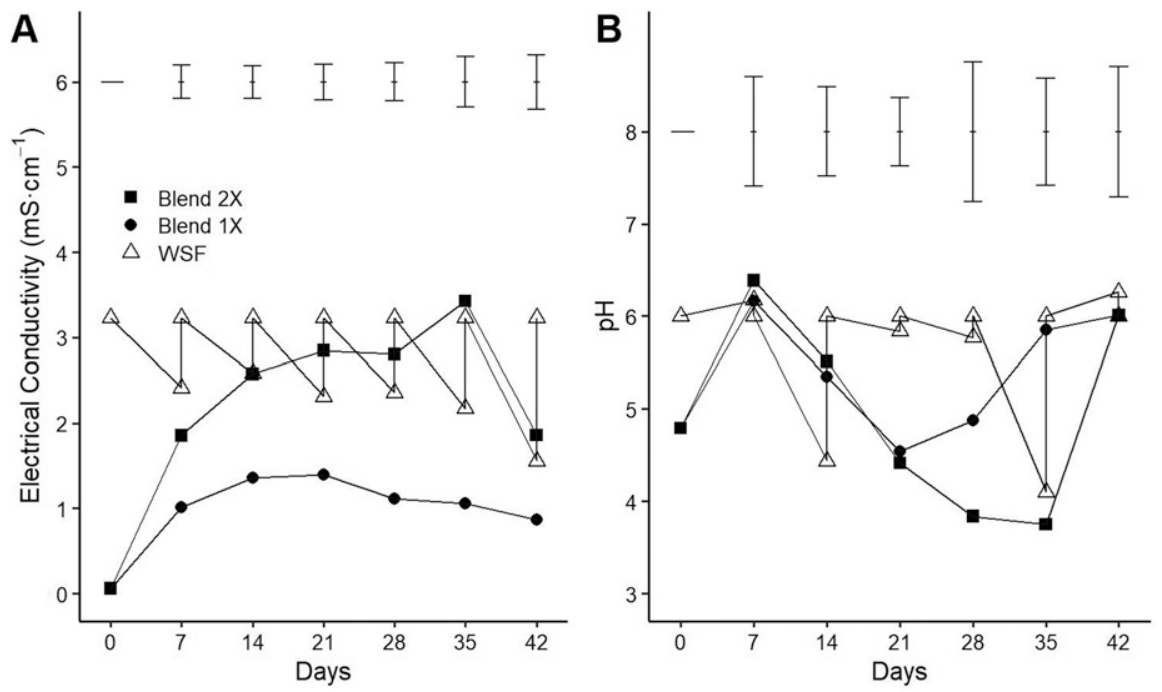

Fig. 5. Nutrient solution electrical conductivity (A) and $\mathrm{pH}(\mathbf{B})$ for nutrient solutions measured after 7 , $14,21,28,35$, and $42 \mathrm{~d}$ of Expt. C. The water-soluble fertilizer (WSF) solution was replaced every week with fresh solution containing $190 \mathrm{mg} \cdot \mathrm{L}^{-1} \mathrm{~N}$ in deionized water. A blended potassium hydroxide plus potassium carbonate base was used to adjust $\mathrm{pH}$ up to 6.0 every time the WSF solution was replenished, but $\mathrm{pH}$ was not corrected in the controlled-release fertilizer treatments. Analysis of variance was run within individual measurement days on eight replicated experimental units per fertilizer treatment. Error bars represent the $95 \%$ confidence intervals around estimated least-square means.

of macronutrients when compared with survey range (Bryson and Mills, 2014) (Table 11). On plants grown under CRF Blend $1 \mathrm{X}$, the aforementioned depletion of $\mathrm{N}, \mathrm{P}$, and $\mathrm{K}$ caused lower levels of these nutrients in tissue when compared with other treatments, and $\mathrm{N}$ levels lower than the ones observed in survey range (Table 11). The lower $\mathrm{N}$ concentration probably limited growth in CRF Blend 1X plants as evidenced by the smaller dry shoot weight found in plants under this treatment (Table 9). High micronutrient levels were found in tissue analysis of plants grown under CRF Blend $2 \mathrm{X}$, which indicates an excess of nutrient supply, although no toxicity symptoms were observed. For future experiments, macronutrient doses should be kept close to those used in CRF Blend 2X, but micronutrient dosage could be significantly reduced to avoid luxury consumption and possible toxicity.

\section{Conclusions}

This study showed proof-of-concept for using CRF blends for small-scale hydroponic production of basil. Off-the-shelf CRF products (CRF Bloom and CRF Plus) were not suitable for a hydroponic system because their nutrient release rate was faster than plant uptake, and nutrient ratios were inadequate for plant growth in solution culture. In both products, micronutrients were unbalanced leading to nutritional disorders, and low calcium levels resulted in tip burn and leaf distortion. It was possible to blend CRF salts to provide macronutrients for hydroponics but limited commercial availability of CRF micronutrients required the use of water-soluble micronutrients at an initial high concentration. All CRF treatments lowered $\mathrm{pH}$ of solutions in plant growth Expts. B and $\mathrm{C}$, presumably as a result of ammonium

Table 10. Residual nutrient solution after basil was cultivated in growth chamber for 6 weeks with nutrient solution made from water-soluble fertilizer (WSF) or customized controlled-release fertilizer (CRF) blend in two different doses in Expt. C. Results for WSF represent depletion of solution over $7 \mathrm{~d}$ (week 5 to week 6).

\begin{tabular}{|c|c|c|c|c|c|c|c|c|c|c|c|c|c|c|}
\hline & $\mathrm{NH}_{4}^{+}-\mathrm{N}$ & $\mathrm{NO}_{3}{ }^{-}-\mathrm{N}$ & total-N & $\mathrm{P}$ & $\mathrm{K}$ & $\mathrm{Ca}$ & $\mathrm{Mg}$ & $\mathrm{S}$ & $\mathrm{Fe}$ & $\mathrm{Mn}$ & B & $\mathrm{Cu}$ & $\mathrm{Zn}$ & Mo \\
\hline Treatment & \multicolumn{14}{|c|}{$\left(\mathrm{mg} \cdot \mathrm{L}^{-1}\right)$} \\
\hline CRF Blend $1 \mathrm{X}$ & $1.3 \mathrm{a}$ & $3.1 \mathrm{c}$ & $4.4 \mathrm{c}$ & $1.5 \mathrm{~b}$ & $8.2 \mathrm{c}$ & $99 \mathrm{~b}$ & $24 \mathrm{~b}$ & $111 \mathrm{~b}$ & $0.40 \mathrm{c}$ & $0.08 \mathrm{~b}$ & $0.24 \mathrm{~b}$ & $0.13 \mathrm{~b}$ & $0.07 \mathrm{~b}$ & $0.03 \mathrm{~b}$ \\
\hline ANOVA & NS & $* * *$ & $* * *$ & $* * *$ & $* * *$ & $* * *$ & $* * *$ & $* * *$ & $* * *$ & $* * *$ & $* * *$ & $* * *$ & $* * *$ & $* * *$ \\
\hline
\end{tabular}

NS $=$ nonsignificant, $* * * P<0.001$. Pairwise comparison between the treatments used Tukey's honestly significant difference test at the $5 \%$ level.

Table 11. Tissue analysis from basil cultivated in growth chamber for 6 weeks with nutrient solution made from water-soluble fertilizer (WSF) or customized controlled-release fertilizer (CRF) blend in two different doses. Pairwise comparison between the treatments used Tukey's honestly significant difference test at the $5 \%$ level.

\begin{tabular}{|c|c|c|c|c|c|c|c|c|c|c|c|c|}
\hline \multirow[b]{2}{*}{ Treatment } & $\mathrm{N}$ & $\mathrm{P}$ & $\mathrm{K}$ & $\mathrm{Ca}$ & $\mathrm{Mg}$ & $\mathrm{S}$ & $\mathrm{Fe}$ & $\mathrm{Mn}$ & B & $\mathrm{Cu}$ & $\mathrm{Zn}$ & Mo \\
\hline & \multicolumn{6}{|c|}{$(\%)$} & \multicolumn{6}{|c|}{$\left(\mathrm{mg} \cdot \mathrm{kg}^{-1}\right)$} \\
\hline$\overline{\mathrm{WSF}}$ & $5.1 \mathrm{a}$ & $1.2 \mathrm{a}$ & $6.0 \mathrm{a}$ & $1.0 \mathrm{ab}$ & 0.5 & $0.5 \mathrm{~b}$ & $305 \mathrm{~b}$ & $320 a$ & $28 \mathrm{~b}$ & $16 \mathrm{~b}$ & $52 \mathrm{~b}$ & $12 \mathrm{c}$ \\
\hline CRF Blend $1 \mathrm{X}$ & $3.4 \mathrm{~b}$ & $0.6 \mathrm{c}$ & $3.7 \mathrm{~b}$ & $0.9 \mathrm{~b}$ & 0.5 & $1.0 \mathrm{a}$ & $394 \mathrm{~b}$ & $132 \mathrm{~b}$ & $29 \mathrm{~b}$ & $69 a$ & $146 \mathrm{a}$ & $40 \mathrm{~b}$ \\
\hline CRF Blend 2X & $4.7 \mathrm{a}$ & $0.9 \mathrm{~b}$ & $5.1 \mathrm{a}$ & $1.2 \mathrm{a}$ & 0.5 & $1.0 \mathrm{a}$ & $725 \mathrm{a}$ & $247 \mathrm{a}$ & $42 \mathrm{a}$ & $78 \mathrm{a}$ & $147 \mathrm{a}$ & $75 \mathrm{a}$ \\
\hline Survey range ${ }^{z}$ & $4-6$ & $0.62-1.0$ & $1.55-2.05$ & $1.25-2.00$ & $0.6-1.0$ & $0.2-0.6$ & $75-200$ & $30-150$ & $25-60$ & $5-10$ & $30-70$ & $0.1-0.5$ \\
\hline ANOVA $^{\mathrm{y}}$ & $* * *$ & $* * *$ & $* * *$ & $*$ & NS & $* *$ & $* *$ & $* * *$ & $* * *$ & $* * *$ & $* * *$ & $* * *$ \\
\hline
\end{tabular}

${ }^{\mathrm{z}}$ Survey ranges from field and garden-grown basil plants in Bryson and Mills (2014).

${ }^{\mathrm{y}}$ Analysis of variance statistical test do not include survey ranges.

NS $=$ nonsignificant, ${ }^{*} P<0.05, * * P<0.01, * * * P<0.001$. 
in fertilizers. Future research should address micronutrient management, plant species type, crop duration, and water-quality impact on CRF-based hydroponic solutions to validate CRF use as a reliable and simple fertilization strategy in small-scale hydroponics.

\section{Literature Cited}

Adams, C., J. Frantz, and B. Bugbee. 2013. Macroand micronutrient-release characteristics of three polymer-coated fertilizers: Theory and measurements. J. Plant Nutr. Soil Sci. 176:76-88.

Albaho, M., D. Ghloum, B. Thomas, S. Isathali, and P. George. 2010. Effect of two fertilizers on growth and yield of chili pepper and cherry tomato grown in a closed insulated pallet system. Acta Hort. 927:879-885.

Broschat, T.K. and K.K. Moore. 2007. Release rates of ammonium-nitrogen, nitrate-nitrogen, phosphorus, potassium, magnesium, iron, and manganese from seven controlled-release fertilizers. Commun. Soil Sci. Plant Anal. 38:843850.

Bryson, M.G. and H.A. Mills. 2014. Plant Analysis Handbook IV. Micro-Macro Publ. Athens, GA.

Bugbee, B. 2004. Nutrient management in recirculating hydroponic culture. Acta Hort. 648:99112.

de Mendiburu, F. 2020. agricolae: Statistical procedures for agricultural research. $\mathrm{R}$ package version 1.3-2. $<$ https://cran.r-project.org/package $=$ agricolae $>$.

Du, C., J. Zhou, and A. Shaviv. 2006. Release characteristics of nutrients from polymercoated compound controlled-release fertilizers. J. Polym. Environ. 14:223-230.

Garden Media Group. 2016. State of the industry report: Trends. 9 Dec. 2019. <http://grow. gardenmediagroup.com/2017-garden-trendsreport>

Gillespie, D.P., C. Kubota, and S.A. Miller. 2020 Effects of low $\mathrm{pH}$ of hydroponic nutrient solution on plant growth, nutrient uptake, and root rot disease incidence of basil (Ocimum basilicum L.). HortScience 55:1251-1258.

Hoagland, D.R. and D.I. Arnon. 1950. The waterculture method for growing plants without soil. Circ. 347. California Agricultural Experiment Station, Berkeley, CA.

Hochmuth, G.J. and R.C. Hochmuth. 2018. Nutrient solution formulation for hydroponic (perlite, rockwool, NFT) tomatoes in Florida. Univ. Florida, Inst. Food Agr. Sci. HS796. 9 Dec. 2019. <https://edis.ifas.ufl.edu/cv216>

Huett, D.O. and B.J. Gogel. 2000. Longevities and nitrogen, phosphorus, and potassium release patterns of polymer-coated controlled-release fertilizers at $30^{\circ} \mathrm{C}$ and $40^{\circ} \mathrm{C}$. Commun. Soil Sci. Plant Anal. 31:959-973.

Kinoshita, T. and M. Masuda. 2011. Differential nutrient uptake and its transport in tomato plants on different fertilizer regimens. HortScience 46:1170-1175.

Kinoshita, T. and M. Masuda. 2012. Effects of different application methods of controlledrelease fertilizers on capillary wick culture of tomato. HortScience 47:1529-1535.

Kinoshita, T., T. Yano, M. Sugiura, and Y. Nagasaki. 2014. Effects of controlled-release fertilizer on leaf area index and fruit yield in high-density soilless tomato culture using low node-order pinching. PLoS One 9:e113074.

Kinoshita, T., H. Yamazaki, K. Inamoto, and H Yamazaki. 2016. Analysis of yield components and dry matter production in a simplified soilless tomato culture system by using controlledrelease fertilizers during summer-winter greenhouse production. Scientia Hort. 202:17-24.

Lenth, R. 2020. emmeans: Estimated Marginal Means, aka Least-Squares Means. R package version 1.4.6. <https://CRAN.R-project.org/ package $=$ emmeans $>$.

Liu, G., L. Zotarelli, Y. Li, D. Dinkins, Q. Wang, and M. Ozores-Hampton. 2017. Controlledrelease and slow-release fertilizers as nutrien management tools. Univ. Florida Inst. Food Agr. Sci. HS1255. 9 Dec. 2019. <https://edis. ifas.ufl.edu/hs1255>.

Massa, G.D., N.F. Dufour, J.A. Carver, M.E Hummerick, R.M. Wheeler, R.C. Morrow, and T.M. Smith. 2017. VEG-01: Veggie hardware validation testing on the International Space Station. Open Agr. 2:33-41.

Mattson, N.S. and C. Peters. 2014. A recipe for hydroponic success. Inside Grower 2014 (Jan.):16-19. <http://www.greenhouse.cornell. edu/crops/factsheets/hydroponic-recipes.pdfs.

Merhaut, D.J., E.K. Blythe, J.P. Newman, and J.P. Albano. 2006. Nutrient release from controlledrelease fertilizers in acid substrate in a greenhouse environment: II. Leachate calcium, magnesium, iron, manganese, zinc, copper, and molybdenum concentrations. HortScience 41:788-793.

Monje, O., G.W. Stutte, G.D. Goins, D.M. Porterfield, and G.E. Bingham. 2003. Farming in space: Environmental and biophysical concerns. Adv Space Res. 31:151-167.

Morgan, K.T., K.E. Cushman, and S. Sato. 2009 Release mechanisms for slow-and controlledrelease fertilizers and strategies for their use in vegetable production. HortTechnology 19:10-12.

National Gardening Association. 2014. Garden to table: A 5-year look at food gardening in America. Natl. Gardening Assoc. 9 Dec. 2019. $<$ https://garden.org/special/pdf/2014-NGAGarden-to-Table.pdf>.

Oertli, J.J. 1980. Controlled-release fertilizers. Fert. Res. 1:103-123.

Ozores-Hampton, M. 2017. Methods for measuring nitrogen release from controlled-release fertilizer used for vegetable production. Univ. Florida Inst. Food Agr. Sci. HS1227. 9 Dec. 2019. $<$ https://edis.ifas.ufl.edu/hs1227>.
R Core Team. 2020. R: A language and environment for statistical computing. R Foundation for Statistical Computing, Vienna, Austria. $<$ https://www.r-project.org $>$.

Resh, H.M. 2013. Hydroponic food production: A definitive guidebook for the advanced home gardener and the commercial hydroponic grower. CRC Press, Boca Raton, FL.

Resh, H.M. 2015. Hydroponics for the home grower. CRC Press, Boca Raton, FL.

Savvas, D., G. Gianquinto, Y. Tüzel, and N. Gruda. 2013. Soilless culture, p. 303-354. In: Good agricultural practices for greenhouse vegetable crops. Principles for Mediterranean climate areas. FAO, Plant Production and Protection Paper 217, Rome, Italy. <http://www.fao.org/ docrep/018/i3284e/i3284e.pdf $>$.

Schnitzler, W.H., A.K. Sharma, N.S. Gruda, and H.T. Heuberger. 2004. A low-tech hydroponic system for bell pepper (Capsicum Annuum L.) production. Acta Hort. 644:47-53.

Shaviv, A. 2005. Controlled release fertilizers. Intl. Fert. Assn. A Intl. Wkshp.: Enhanced-efficiency fertilizers. 27-30 June 2005. Frankfurt, Germany. 9 Dec. 2019. <https://www.fertilizer.org/images/ Library_Downloads/2005_ag_frankfurt_shaviv_ slides.pdf $>$.

Solis-Toapanta, E., P. Fisher, and C. Gómez. 2020. Growth rate and nutrient uptake of basil in smallscale hydroponics. HortScience 55:507-514.

Sonneveld, C. and W. Voogt. 2009. Nutrient solutions for soilless cultures, p. 257-275. In: Plant nutrition of greenhouse crops. Springer, Dordrecht, The Netherlands.

Steiner, A.A. 1961. A universal method for preparing nutrient solutions of a certain desired composition. Plant Soil 15:134-154.

Stutte, G., R. Wheeler, R. Morrow, and G. Newsham. 2011. Operational evaluation of VEGGIE food production system in the habitat demonstration unit. Proc. 41st Intl. Conf. on Environmental Systems, Portland, OR, 17-21 July 2011.

Trejo-Téllez, L.I. and F.C. Gómez-Merino. 2012 Nutrient solutions for hydroponic systems, p. 1-22. In: T. Asao (ed.). Hydroponics: A standard methodology for plant biological researches. InTech. Rijeka, Croatia.

Trenkel, M.E. 2010. Slow-and controlled-release and stabilized fertilizers: An option for enhancing nutrient use efficiency in agriculture. Intl. Fertilizer Ind. Assn. (IFA). Paris, France.

Walters, K.J. and C.J. Currey. 2018. Effects of nutrient solution concentration and daily light integral on growth and nutrient concentration of several basil species in hydroponic production. HortScience 53:1319-1325.

Zografou, M. and C. Lykas. 2017. An empirical model to estimate nutrients concentration in controlled release fertilizers aqueous solutions. Proc. 8th Int. Conf. on Info. and Commun Technol. in Agr., Food and Environ., Chiana, Greece, 21-24 Sept. <http://ceur-ws.org/Vol2030/HAICTA_2017_paper16.pdf>. 